\title{
EKSPLORASI MOTIVASI BELAJAR SISWA PADA MATA PELAJARAN PEMELIHARAAN SISTEM KELISTRIKAN KENDARAAN RINGAN
}

\author{
Henro N. M. Faizal ${ }^{1}$, Wowo S. Kuswana' ${ }^{2}$, Tatang Permana ${ }^{3}$ \\ Departemen Pendidikan Teknik Mesin \\ Universitas Pendidikan Indonesia \\ Jl. Dr. Setiabudhi No. 207 Bandung 40154 \\ henrofaisal@gmail.com
}

\begin{abstract}
ABSTRAK
Penelitian ini bertujuan untuk mengetahui kondisi motivasi belajar siswa serta seberapa besar motivasi belajar siswa pada mata pelajaran pemeliharaan sistem kelistrikan kendaraan ringan. Penelitian ini menggunakan desain penelitian deskriptif kuantitatif. Instrumen penelitian yang digunakan berupa angket. Penelitian ini dilaksanakan dikelas XI Teknik Kendaraan Ringan SMK Negeri 8 Bandung. Instrumen penelitian menggunakan angket dengan skala Likert dan aspek yang diukur yaitu sikap, pendapat atau persepsi seseorang. Hasil penelitian motivasi belajar siswa sebesar 79,36\%. Data ini menunjukkan bahwa motivasi belajar siswa SMK sebagian besar siswa memiliki motivasi belajar untuk melaksanakan pembelajaran.
\end{abstract}

Kata kunci: motivasi, pemeliharaan, sistem kelistrikan, kendaraan ringan

\section{PENDAHULUAN}

Pendidikan adalah salah satu bentuk perwujudan kebudayaan manusia yang dinamis dan sarat perkembangan, karena itu perubahan atau perkembangan pendidikan adalah hal yang memang seharusnya terjadi sejalan dengan perubahan budaya kehidupan. Berkembangnya dunia pendidikan pada saat ini merupakan tantangan untuk mengembangkan kemampuan dalam dunia pendidikan. Undang-undang Nomor 20 Tahun 2003 tentang Sistem Pendidikan Nasional, Pasal 3 menyatakan bahwa: Pendidikan nasional berfungsi mengembangkan kemampuan serta membentuk watak dan peradaban bangsa yang bermartabat dalam rangka mencerdaskan kehidupan bangsa, bertujuan untuk mengembangkan potensi peserta didik agar menjadi manusia yang beriman dan bertakwa kepada Tuhan Yang Maha Esa, berakhlak mulia, sehat, berilmu, cakap, kreatif, mandiri, dan menjadi warga negara yang demokratis serta bertanggung jawab.

Agar tercapai tujuan pendidikan nasional yang antara lain yaitu meningkatkan ketaqwaan kepada Tuhan Yang Maha Esa, kecerdasan dan keterampilan maka salah satu usaha yang ditingkatkan adalah menumbuhkan kemandirian belajar pada siswa diberbagai sekolah, dengan menumbuhkan motivasi belajar pada setiap diri siswa. Mengenai masalah pendidikan, menyangkut masalah tentang lingkungan pendidikan, yang dikenal dengan tripusat pendidikan, yaitu lingkungan keluarga, lingkungan sekolah dan lingkungan

\footnotetext{
${ }^{1}$ Mahasiswa Departemen Pendidikan Teknik Mesin FPTK UPI

2 Dosen Departemen Pendidikan Teknik Mesin FPTK UPI

${ }^{3}$ Dosen Departemen Pendidikan Teknik Mesin FPTK UPI
} 
masyarakat. Lingkungan pendidikan yang paling berpengaruh dalam menumbuhkan motivasi belajar adalah lingkungan sekolah.

Lingkungan sekolah khususnya Sekolah Menengah Kejuruan (SMK) yang merupakan suatu lembaga pendidikan formal, lulusannya dipersiapkan untuk memasuki dunia kerja dan memiliki kemampuan yang sesuai dengan kebutuhan industri. Sekolah bukan saja mengharapkan siswa yang mampu, cakap, dan terampil, tetapi yang terpenting mereka mau giat belajar dan berkeinginan untuk mencapai hasil belajar yang optimal. Kemampuan, kecakapan, dan keterampilan tidak ada artinya jika mereka tidak mau bekerja keras dengan mempergunakan kemampuan, kecakapan, dan keterampilan yang dimilikinya. Adanya motivasi diharapkan individu siswa mau bekerja keras dan antusias untuk mencapai produktivitas yang tinggi (Hamalik, 2014).

Sebagai upaya mewujudkan tujuan pendidikan tidak lepas dari peranan seorang guru di sekolah. Bagaimana cara guru menumbuhkan motivasi belajar di sekolah. Diperlukan usaha yang optimal untuk mencapai tujuan tersebut. Keberhasilan pada dasarnya tidak mungkin dapat dicapai, tanpa didasari oleh motivasi yang tinggi dan kecenderungan untuk menguasai kondisi lingkungan yang dinyatakan lewat sikap. Motivasi belajar diberikan guru kepada siswa agar dapat terjadi proses pemerolehan ilmu pengetahuan, penguasaan kemahiran, serta pembentukan sikap dan kepercayaan diri siswa. Motivasi belajar adalah proses untuk mendorong siswa agar dapat belajar untuk meraih prestasi yang lebih baik (Uno, 2014).

Proses pendidikan dapat ditinjau dari tingkat keberhasilan belajar siswa, pada suatu pembelajaran di pengaruhi oleh berbagai faktor, baik yang berasal dari dalam diri sendiri (faktor intern) maupun yang berasal dari luar diri sendiri (faktor ekstern). Faktor yang bersifat intern, misalnya: kecerdasan, bakat, minat, perhatian, motovasi, sikap, kesehatan jasmani, dan aktivitas belajar. Sedangkan faktor yang bersifat ekstern, misalnya: lingkungan alam, lingkungan masyarakat, lingkungan sekolah dan sarana belajar. Faktor intern adalah faktor yang ada dalam diri individu yang sedang belajar, sedangkan faktor ekstern adalah faktor yang ada di luar individu.

Berdasarkan hasil pengamatan, masih ada siswa yang kurang termotivasi dalam melaksanakan pembelajaran, hal ini ditandai dengan malasnya mengerjakan tugas, sering tidak masuk kelas, dan sebagainya. Ciri-ciri siswa yang kurang memiliki motivasi belajar dilihat dari perilakunya, antara lain: malas dalam mengerjakan tugas yang diberikan oleh guru, sering membolos saat proses belajar mengajar, sering terlambat dalam mengumpulkan 
tugas, kurang ulet/mudah menyerah saat mengalami kesulitan (cepat putus asa), dan kurang memiliki kreativitas, hanya cenderung mengikuti teman-temannya (Sampurnawati, 2009).

Contoh nyata yaitu pada saat guru memberikan tugas, masih ada siswa yang tidak mengerjakan tugas yang diberikan oleh guru. Ini bisa dilihat dari rendahnya hasil belajar siswa pada pembelajaran pemeliharaan sistem kelistrikan kendaraan ringan. Masih ada siswa yang kurang memiliki motivasi dalam melaksanakan pembelajaran sehingga hasil belajarnyapun kurang begitu baik. Meskipun kenyataannya tidak semua siswa melakukannya, namun terdapat sebagian siswa yang melakukan kelalaian-kelalaian dalam hal belajar, misalnya: malas belajar, malas mengerjakan tugas, dan tidak mempersiapkan diri untuk mengikuti pelajaran. Tentunya salah satu penyebab karena siswa tidak memiliki motivasi yang tinggi, disamping faktor yang lainnya. Apabila siswa memiliki motivasi belajar tinggi, maka prestasi belajarnya baik. Terdapat pengaruh yang signifikan antara motivasi belajar terhadap prestasi belajar yaitu sebesar 75,3\% (Rafiqah, 2012). Motivasi dapat memengaruhi apa yang kita pelajari, kapan kita belajar, dan bagaimana cara kita belajar (Schunk, Pintrich, dan Meece, 2012).

\section{METODE PENELITIAN}

Metode yang digunakan dalam penelitian ini adalah metode penelitian deskriptif dengan pendekatan kuantitatif. Penelitian deskriptif merupakan penelitian dengan tujuan mendeskripsikan atau memberi gambaran terhadap objek yang diteliti melalui data sampel atau populasi sebagaimana adanya tanpa melakukan analisis dan membuat kesimpulan. Pendekatan yang digunakan dalam penelitian ini adalah penelitian survey dengan bentuk data kuantitatif, karena data berbentuk data-data yang dideskripsikan. Penelitian deskriptif dalam penelitian ini, dimaksudkan untuk mendapatkan data mengenai motivasi belajar siswa kelas XI TKR 3 dan XI TKR 4 di SMKN 8 Bandung tahun 2015/2016. Populasi dan sampel dalam penelitian ini adalah siswa kelas XI TKR 3 sebanyak 22 orang, XI TKR 4 sebanyak 24 orang yang berjumlah 46 orang. Teknik sampling yang digunakan adalah teknik purposive sampling.

Instrumen yang digunakan pada penelitian ini yaitu menggunakan metode angket/kuesioner untuk mengukur motivasi belajar siswa SMK Negeri 8 Bandung pada mata pelajaran pemeliharaan sistem kelistrikan kendaraan ringan. Analisis data merupakan tahapan dalam mengolah data hasil penelitian ke dalam bentuk persentase yang selanjutnya akan dideskripsikan, sehingga data tersebut dapat dibuat ke dalam uraian yang lebih rinci, jelas, 
sistematis dan dapat dipercaya. Adapun tahapan dalam menganalisis data pada penelitian ini yaitu; (1) persiapan, (2) tabulasi data, (3) pengolahan data.

\section{HASIL PENELITIAN}

Motivasi belajar berdasarkan minat, sebagian besar siswa $(81,30 \%)$ mempunyai motivasi belajar untuk memperhatikan penjelasan guru di kelas sampai jam pelajaran berakhir. Motivasi belajar berdasarkan kemandirian sebanyak 64,78\% siswa mempunyai motivasi belajar untuk membaca kembali materi pelajaran pemeliharaan sistem kelistrikan kendaraan ringan di rumah minimal satu jam. Sebanyak 72,6\% siswa mempunyai motivasi belajar karena meluangkan waktu untuk menghapal materi pelajaran pemeliharaan sistem kelistrikan kendaraan ringan yang baru diajarkan guru. Sebanyak 66,1\% siswa mempunyai motivasi belajar karena membuat ringkasan materi pembelajaran pemeliharaan sistem kelistrikan kendaraan ringan yang telah disampaikan guru di kelas. Sebanyak $86,1 \%$ siswa mempunyai motivasi belajar karena akan belajar kelompok bersama teman-temannya apabila mendapat kesulitan dalam mempelajari materi pelajaran pemeliharaan sistem kelistrikan kendaraan ringan. Lebih dari setengahnya siswa $(61,74 \%)$ mempunyai motivasi belajar karena memanfaatkan waktu luang untuk pergi ke perpustakaan untuk membaca buku-buku pelajaran pemeliharaan sistem kelistrikan kendaraan ringan. Sebagian besar siswa $(78,26 \%)$ mempunyai motivasi belajar karena mempersiapkan diri ketika menghadapi tes dengan menambah jam belajar. Sebanyak besar siswa 83,04\% mengerjakan tugas secara maksimal. Sebesar 73,04\% siswa membaca buku lain di luar buku/modul yang dianjurkan guru untuk menambah bahan dalam mengerjakan tugas.

Motivasi belajar berdasarkan kemauan sebagian besar siswa $(85,22 \%)$ mempunyai motivasi menanyakan kepada guru, apabla menemukan soal yang sulit untuk dikerjakan Sebagian besar siswa $(79,57 \%)$ tidak mempunyai motivasi belajar dan menunda-nunda mengerjakan tugas yang diberikan guru. Sebanyak 84,78\% siswa mempunyai motivasi belajar untuk menanyakan kepada guru jika kurang paham pada tugas yang diberikan guru. Sebanyak 69,57\% siswa mempunyai motivasi belajar karena akan mencari referensi lain diluar jam pelajaran, bila tidak paham dengan penjelasan guru. Sebagian besar siswa $(90,43 \%)$ mempunyai motivasi belajar karena ingin mendapatkan hasil yang baik pada pembelajaran. Sebanyak $84,78 \%$ siswa mempunyai motivasi belajar karena selalu datang tepat waktu untuk mengikuti pembelajaran pemeliharaan sistem kelistrikan kendaraan ringan. Sebanyak 70,00\% 
siswa mempunyai motivasi belajar karena rela menggunakan waktu bermain untuk mengerjakan tugas.

Motivasi belajar berdasarkan nilai ulangan, sebagian besar siswa (90,87\%) mempunyai motivasi selalu berusaha mendapat nilai baik. Sebanyak 86,52\% siswa mempunyai motivasi belajar karena berusaha secara maksimal menjawab soal-soal pada saat melaksanakan tes.

Motivasi belajar berdasarkan kepercayaan diri dalam belajar, sebagian besar siswa $(77,83 \%)$ mempunyai motivasi karena selalu percaya diri pada saat menjawab pertanyaan guru di kelas. Sebanyak 75,65\% siswa mempunyai motivasi belajar untuk mampu mendapat nilai lebih baik dari teman-teman.

Motivasi belajar berdasarkan orientasi pada hasil, sebagian besar siswa $(85,65 \%)$ mempunyai motivasi, karena selalu berusaha mendapatkan nilai terbaik diantara teman-teman satu kelas. Sebanyak 86,96\% siswa mempunyai motivasi belajar karena menargetkan nilai tes yang lebih baik dari nilai tes yang sebelumnya. Sebanyak $82,61 \%$ siswa mempunyai motivasi belajar karena dengan menyelesaikan tugas-tugas dalam pembelajaran akan merasa puas terhadap hasil yang telah dicapai. Sebagian $87,39 \%$ siswa mempunyai motivasi belajar karena dengan menyelesaikan pembelajaran dengan berhasil sangat penting.

Siswa yang memiliki motivasi belajar berdasarkan indikator minat sebesar 4,26\%, siswa yang memiliki motivasi belajar berdasarkan indikator kemandirian sebesar 30,75\%. Siswa yang memiliki motivasi belajar berdasarkan indikator kemauan sebesar 29,63\%. Siswa yang memiliki motivasi belajar berdasarkan indikator nilai ulangan sebesar 9,31\%. Siswa yang memiliki motivasi belajar berdasarkan indikator kepercayaan diri dalam belajar sebesar $17,99 \%$. Serta siswa yang memiliki motivasi belajar berdasarkan indikator orientasi pada hasil sebesar $8,06 \%$.

\section{PEMBAHASAN}

Data mengenai motivasi belajar telah dikemukakan tiap indikator pada temuan penelitian diatas. Setelah data mengenai motivasi belajar diketahui, selanjutnya dilakukan pembahasan. Pembahasan data akan penulis bahas tiap indikator, dari mulai indikator minat, kemandirian, kemauan, nilai ulangan, kepercayaan diri dalam belajar, dan orientasi pada hasil (Noor, 2009). Setelah membahas tiap indikator, selanjutnya penulis akan membahas seberapa besar motivasi belajar siswa SMK Negeri 8 Bandung. 
Ada tiga jenis teori motivasi, yaitu motivasi dengan pendekatan perilaku, motivasi dengan pendekatan humanistik, dan motivasi dengan pendekatan kognitif. Pertama, motivasi dengan pendekatan perilaku dideskripsikan oleh indikator minat, kemandirian, serta kemauan. Kedua, motivasi dengan pendekatan humanistik dideskripsikan oleh indikator nilai ulangan. Ketiga, motivasi dengan pendekatan kognitif dideskripsikan oleh indikator kepercayaan diri dalam belajar dan orientasi pada hasil (Rahmawati, 2013)..

Pertama, motivasi dengan pendekatan perilaku. Motivasi dengan pendekatan perilaku yang dideskripsikan oleh indikator minat, yaitu saya memperhatikan penjelasan guru di kelas sampai jam pelajaran berakhir, persentasenya sebesar 81,30\%. Ini menunjukkan bahwa sebagian besar siswa memiliki motivasi untuk melaksanakan pembelajaran. Persentase ratarata pada indikator ini adalah sebesar $81,30 \%$, artinya sebagian besar siswa memiliki motivasi belajar. Kemudian motivasi dengan pendekatan perilaku yang dideskripsikan oleh indikator kemandirian. Dilihat dari persentasenya, yang sangat mempengaruhi motivasi belajar siswa, yaitu sebesar 86,09\%. Siswa akan belajar kelompok bersama teman-temannya apabila mendapat kesulitan dalam mempelajari materi pelajaran pemeliharaan sistem kelistrikan kendaraan ringan. Sementara persentase terendah ditunjukkan oleh pernyataan, saya memanfaatkan waktu luang untuk pergi ke perpustakaan untuk membaca buku-buku pelajaran pemeliharaan sistem kelistrikan kendaraan ringan, persentasenya sebesar $61,74 \%$. Ini menunjukkan bahwa siswa lebih memilih untuk belajar kelompok bersama teman-temnnya untuk mempelajari materi pemeliharaan sistem kendaraan ringan daripada harus pergi ke perpustakaan untuk membaca materi terkait pemeliharaan sistem kelistrikan kendaraan ringan. Persentase rata-rata pada indikator kemandirian ini adalah $73,21 \%$, artinya sebagian lebih dari setengahnya siswa memiliki motivasi belajar.

Motivasi dengan pendekatan perilaku yang selanjutnya dideskripsikan oleh indikator kemauan. Persentase tertinggi pada indikator kemauan ini adalah saya ingin mendapat hasil yang baik pada pembelajaran ini, sebesar $90,43 \%$. Sementara persentase terendahnya adalah saya akan mencari referensi lain diluar jam pelajaran, bila saya tidak paham dengan penjelasan guru. Ini menunjukkan bahwa sebagian besar siswa ingin mendapatkan hasil yang baik, namun hanya lebih dari setengahnya siswa yang mau mencari referensi lain apabila tidak paham dengan penjelasan guru. Persentase rata-rata pada indikator kemauan ini sebesar $80,62 \%$, artinya sebagian besar siswa memiliki motivasi belajar.

Kedua, motivasi dengan pendekatan humanistik. Motivasi dengan pendekatan humanistik dideskripsikan oleh indikator nilai ulangan. Indikator saya selalu berusaha 
mendapat nilai baik memiliki persentase sebesar 90,87\%. Sedangkan pernyataan saya berusaha secara maksimal menjawab soal-soal pada saat melaksanakan tes memilki persentase sebesar 86,52\%. Ini menunjukkan bahwa sebagian besar siswa selalu ingin mendapatkan nilai ulangan yang baik. Untuk mendapatkan nilai ulangan yang baik perlu ditunjang dengan memperhatikan faktor hubungan antara guru dan siswa dan faktor iklim kelas yang kondusif. Apabila kedua faktor tersebut dilaksanakan dengan baik, bukan tidak mungkin siswa akan mendapatkan nilai ulangan yang baik. Persentase rata-rata pada indikator nilai ulangan ini sebesar $88,70 \%$, artinya sebagian besar siswa memiliki motivasi belajar.

Ketiga, motivasi belajar dengan pendekatan kognitif. Motivasi dengan pendekatan kognitif yang dideskripsikan oleh indikator kepercayaan diri dalam belajar. Pernyataan saya selalu percaya diri pada saat menjawab pertanyaan di kelas, memiliki persentse sebesar $77,83 \%$. Sedangkan pernyataan nomor 24 yaitu saya mampu mendapat nilai lebih baik dari teman-teman, memiliki persentase sebesar 75,65\%. Ini menunjukkan bahwa sebagian besar siswa memiliki kepercayaan diri pada saat menjawab pertanyaan guru di kelas, tetapi hanya lebih dari setengahnya siswa yang merasa mampu mendapat nilai lebih baik dari temannnya. Untuk menubuhkan kepercayaan diri pada siswa, perlu adanya persaingan antara siswa itu sendiri, tentunya persaingan secara sehat. Persentase rata-rata pada indikator kepercayaan diri dalam belajar sebesar 76,74\%, artinya sebagian besar siswa memiliki motivasi belajar.

Motivasi dengan pendekatan kognitif yang selanjutnya dideskripsikan oleh indikator orientasi pada hasil. Dilihat dari persentasenya, yang sangat mempengaruhi motivasi belajar adalah pernyataan $\mathrm{n}$ menyelesaikan pembelajaran dengan berhasil sangat penting bagi saya, memiliki persentase $87,39 \%$. Sedangkan persentase terendah pada indikator ini adalah pernyataan menyelesaikan tugas-tugas dalam pembelajaran ini membuat saya merasa puas terhadap hasil yamg telah saya capai, memiliki persentase sebesar $82,61 \%$. Ini menunjukkan bahwa pada indikator orientasi pada hasil ini sebagian besar siswa memiliki motivasi untuk menyelesaikan tugas ataupun menyelesaikan pembelajaran secara berhasil, karena dengan menyelesaikan tugas atau menyelesaikan pembelajaran secara berhasil akan membuat diri siswa puas. Persentase rata-rata pada indikator orientasi pada hasil ini sebesar 85,6\%, artinya sebagian besar siswa memiliki motivasi belajar.

Apabila persentase dari setiap indikator direntangkan dari 0-100\% akan terlihat perbedaan persentase dari setiap konsep teori sesuai indikator yang mendeskripsikannya. Untuk konsep teori dengan pendekatan perilaku yaitu indikator minat, kemandirian dan kemauan, apabila dijumlahkan adalah sebesar 64,6\%. Untuk konsep teori dengan pendekatan 
humanistik yaitu indikator nilai ulangan sebesar 9,3\%. Untuk konsep teori dengan pendekatan kognitif yaitu indikator kepercayaan diri dalam belajar dan orientasi pada hasil apabila dijumlahkan adalah sebesar $26,1 \%$.

Sementara untuk persentase keseluruhan motivasi belajar siswa SMK Negeri 8 Bandung adalah sebesar 79,4\%. Artinya sebagian besar siswa SMK Negeri 8 Bandung memiliki motivasi belajar, khususnya pada pembelajaran pemeliharaan sistem kelistrikan kendaraan ringan. Melihat dari hasil tersebut, bahwa motivasi dapat dilihat dari beberapa indikator, yaitu indikator minat, kemandirian, kemauan, nilai ulangan, kepercayaan diri dalam belajar dan orientasi pada hasil (Djamarah, 2011). Melihat dari persentase tersebut, diharapkan pembelajaran berlangsung baik khususnya pada pembelajaran sistem pemeliharaan kelistrikan kendaraan ringan.

\section{KESIMPULAN}

Kesimpulan penelitian ini yaitu motivasi belajar siswa SMK menunjukkan kondisi yang baik. Persentase rata-rata tiap indikator, yaitu sebagian besar siswa memiliki motivasi belajar. Hanya pada indikator kemandirian saja yang terlihat kurang baik dalam belajar. Motivasi belajar siswa SMK Negeri 8 Bandung untuk melaksanakan pembelajaran, khususnya pada pembelajaran pemeliharaan sistem kelistrikan kendaraan ringan baik, sebagian besar memiliki motivasi untuk melaksanakan pembelajaran.

\section{DAFTAR PUSTAKA}

Djamarah, S. B. (2011). Psikologi Belajar. (edisi kedua). Jakarta: Rineka Cipta.

Noor, H. (2009). Psikometri: Aplikasi dalam Penyusunan Instrumen Pengukuran Perilaku. (edisi kesatu). Bandung: Fakultas Psikologi UNISBA.

Hamalik, O. (2014). Kurikulum dan Pembelajaran. Jakarta: Bumi Aksara.

Rafiqah, M. (2012). Pengaruh Motivasi Belajar Terhadap Prestasi Belajar. Jurnal Bimbingan Konseling, 2 (2).

Rahmawati, A. K. (2013). Pentingnya Meningkatkan Motivasi Belajar Pada Anak. Jurnal Ilmiah, Universitas Negeri Semarang.

Sampurnawati, E. (2009). Upaya Meningkatkan Motivasi Belajar Melalui Bimbingan Kelompok Pada Siswa. Jurnal Bimbingan dan Konseling, IKIP Veteran Semarang. 
Schunk, D. H., Pintrich, P. R. \& Meece, J. L. (2012). Motivasi dalam Pendidikan: Teori, Penelitian, dan Aplikasi. (edisi ketiga).

Uno, H. B. (2014). Teori Motivasi dan Pengukurannya: Analisis dibidang Pendidikan. Jakarta: Bumi Aksara. 